VISONTAI-SZABÓ Katalin

DOI: 10.15170/DIKE.2021.05.01.12

adjunktus

SZTE ÁJK

\title{
A gyermekjogok szabályozása és e jogok érvényesülése a szülők „válása” esetén
}

\begin{abstract}
Development and Ensuring the Rights of the Child in the Event of Parental "Divorce"
Ellen Key was right when, in 1902, she predicted that the $20^{\text {th }}$ century would be the century of the children. From the brief historical description of my study, it can be seen, that the treatment of children changed a lot in the 1900s, they turned from little adults owned by their parents to individuals with independent rights, who deserve protection. The rights of children are guaranteed by many national and international documents, which I tried to collect. The greatest burden for children is the dissolution of the parent's relationship, so it is particularly important in this process that the parents and the authorities take into account the children's rights, focus on the child's best interests in their decisions and protect them from physical and mental harm.
\end{abstract}

Keywords: child's rights, child's best interest, divorce, family dissolution, parental responsibility

\section{Bevezetés}

A „válás” egy a köznyelvben használatos kifejezés, semmiképp nem nevezhetjük jogászi terminus technikusnak, mégis ezt választottam tanulmányom címeként, mert lényegesen szélesebb kört fed le, mint a bontás kifejezés. Ha a kérdést a gyermek oldaláról közelítjük meg, nincs jelentősége annak, hogy a szülei házasságban vagy élettársi kapcsolatban éltek, esetleg egy alkalmi vagy hosszabb távú, de eltitkolt kapcsolatból született, a szülők kapcsolatának megromlása rá mindenképpen negatívan hat. Jogi szempontból - amennyiben az apai jogállás rendezett - a szülők jogai és kötelezettségei egyenlőek, a szülői felügyelet gyakorlására, ellenkező megállapodás vagy rendelkezés hiányában, közösen jogosultak. Természetesen minden gyermek - függetlenül attól, hogy a szülei milyen kapcsolatban állnak egymással - azonos jogokkal rendelkezik, melyet többek között az 1991. évi LXIV. törvénnyel kihirdetett a Gyermek Jogairól szóló Egyezmény garantál számukra.

A gyermeknek az egészséges személyiségfejlődéséhez családra van szüksége, kiemelkedő jelentősége van tehát annak, hogy a család a szülók kapcsolatának esetleges felbomlása ellenére is megmaradjon. Óvatos becslések szerint minden harmadik gyermek érintett lehet, ${ }^{1}$ különösen nagy felelőssége van tehát a szülőknek, hiszen az ő feladatuk, hogy gyermeküket a testi és lelki károsodásoktól megóvják. A szülők kapcsolatának felbomlása során és azt követően is tekintettel kell lenni a gyermek jogaira és a legfőbb érdekére. Előbbi annyiban könnyebb, hogy számtalan

\footnotetext{
${ }^{1}$ GYURKÓ, Rám is gondoljatok 19.
} 
nemzetközi és nemzeti dokumentum, jogszabály és iránymutatás, valamint a hozzájuk kapcsolódó kiforrott joggyakorlat áll rendelkezésre, amelyek kijelölik a helyes utat a gyermekkel való bánásmód területén. A gyermek legfőbb érdekének szem előtt tartása már nem ennyire egyszerű, hiszen legtöbbször már annak meghatározása is nehézségekbe ütközik. Sőt abban sincsen egyetértés, hogy ki jogosult, illetve képes megmondani, hogy mi szolgálja a gyermek legfőbb érdekét.

\section{A gyermekekkel való bánásmód változásai az európai kultúrában}

A gyermekek helyzete az európai kultúrában rendkívüli átalakuláson eset át az ókori keleti, kánaáni rituális gyermekáldozatoktól a 20. század második feléig. A kiszolgáltatottság jellege és mértéke területenként, népenként változatosságot mutatott. Egyiptomban a gyermeket alapvetően értéknek tartották és megbecsülték, tilos volt a gyermekgyilkosság. A görög világban a gyermeket a jövő szimbólumának tekintették, a nevelést fontosnak tartották, ennek során a verést csak végső esetben alkalmazták, de a torzszülöttek rituális elpusztítása elfogadott volt. A római kultúrában kiemelkedő jelentősége volt a gyermeknevelés során a szigornak, elsősorban a fiúk esetében, hiszen fontos volt, hogy derék férfi váljon belőle, aki katonás erényekkel rendelkezik. Általánosságban megállapítható, hogy patriarchális család keretei között az atyai hatalom határozta meg a gyermeki létet és életét. ${ }^{2}$

A középkor gyermekszemlélete és a középkori gyermekfelfogás - megbízható források hiányában - máig vita tárgya. Aričs és DeMause feltételezését - miszerint a középkori ember nem ismerte volna a gyermekkort - ma már sok kutató nem tartja igaznak. Fontos változásnak tekinthető, hogy a keresztény kultúrában - az ószövetségi írásokkal azonos módon - már halálos bűnnek tekintették a gyermekgyilkosságot, mint ahogy ez az emberélet kiontására általában is igaz volt, és a kereszténység európai terjedése - ha nem is kiszorította, de - háttérbe kényszerítette a pogány kor szokásait és felfogását. Sžent Ágoston Biblia-értelmezésében jelentősége volt annak is, hogy minden gyermek az eredendő bűnt, Ádám és Éva engedetlenségét a Teremtô parancsával szemben magában hordozva jön világra. Ezért a nevelő feladata az, hogy jó irányba fordítsa a gyermek személyiségfejlődését és sorsát. ${ }^{3}$ Más kérdés, hogy ennek során akár a testi fenyítés is megengedett volt. A középkor vége felé a gyermekkort jelentéktelen, átmeneti időszaknak tartották, elsősorban teherként tekintettek rá, amin minél előbb túl kellett esni. Nem volt jellemző a gyermekekkel való szeretetteljes, gyengéd bánásmód. Az anyák a nem kívánt gyermeket, bár az egyház ezt mélyen elítélte és tiltotta, nem egyszer megölték vagy sorsára hagyták. A társadalom felsőbb rétegeihez tartozó anyák is, akik megtartották gyermeküket, gyakran dajkához adták, mert a szoptatást és a csecsemő gondozását visszataszítónak tartották. Sok gyermek nevelkedett tehát szüleitől távol nagyobb életkorában is, például kolostorban. A nem megfelelő gondoskodás, az anyai szeretet hiánya és a kifogásolható higiénés körülmények miatt a gyermekek döntő többsége nem érte meg a felnőttkort. ${ }^{4}$

A reformáció és a kora újkor gyermekképe már területenként erősebb változatosságot mutat, melyre komoly hatással volt a lutheri és kálvini tanokból gyökerezett protestáns életideál,

\footnotetext{
2 PUKÁNSZKY, A gyermekkor története 34-55.

${ }^{3}$ HOLLÓSI, Gyermekkép, gyermekvilág, gyermekfelfogás változásai pedagógiai megközelítésben 95.

${ }^{4}$ PUKÁNSZKY, A gyermekkor története 58-80.
} 
illetve az Angliából kiindult puritanizmus gyermekfelfogása. Ezek szerint a család legfőbb feladata a gyermek következetes, szigorú erkölcsi elvek szerinti nevelése. A korabeli nevelési útmutatók és illemtankönyvek szerzői - például Comenius és Locke - jelentős hatást gyakoroltak a szülőkre és a nevelőkre. Meghatározó továbbá az alapfokú iskoláztatás térnyerése, illetve egy új szülői attitűd, melyet a szigor és engedékenység, a kötődés és a távolítás ambivalenciája jellemez. ${ }^{5}$

A 18. századot Pukánszkey Béla a nevelés évszázadának nevezi. Ebben az időszakban az általános életkörülmények és ennek nyomán a demográfiai mutatók is sokat javultak. A század második felétől bekövetkező szülói, nevelői mentalitás-változás okait Pukánszłky a családok szerepének megváltozásában, az egyéniség újra fontossá válásában, továbbá a gyermek szerepének felértékelődésében látja. ${ }^{6}$ A gyermek szempontjából a leglényegesebb változás a szülői törődés kezdetleges formáinak megjelenése, egyre kevésbé jellemző a dajkaság és a gyermekgyilkosság, a csecsemőhalandóság csökken, a várható élettartam nő. A század vége felé közeledve új családformák jelennek meg, a házastársak között már nem jellemző a nagy korkülönbség. A nukleáris családokban csökken a gyermekek száma, szerepük és jelentőségük felértékelődik, egyre több szülői figyelemre és törődésre számíthatnak. Ezzel párhuzamosan azonban egyre inkább elterjed a gyermekmunka, a gyermekek kizsákmányolása.

A 19. század a változások kora, melynek uralkodó gyermekattitúdje a gyermek szocializációja, társadalmasítása köré rendeződik. A nők fő tevékenységi köre továbbra is a családon belül marad, legfontosabb feladatuk az otthon harmóniájának megteremtése. A polgári lakásokban ekkor jelenik meg először a gyerekszoba, a gyermekágy. A gyermekkor felfedezéséről árulkodik, hogy megjelenik a gyermekjátékok tömeges gyártása és a gyermekeknek szánt irodalom. Ekkor kezdődik a gyermek családi szocializációja, állampolgárrá nevelése. ${ }^{8} \mathrm{Az}$ apa és az anya szerepe is megváltozik, egyre inkább közelít a mai ideálhoz, de sokan még mindig visszaélnek a gyermek kiszolgáltatott helyzetével. Az anyaság is átértékelődik, ${ }^{9}$ már a szülés előtt tudatosan készül a gyermeke fogadására. A szoptatós dajkák teljesen eltűnnek, viszont a dolgozó apa egyre jobban elszigetelődik gyermekeitől.

A 20. század egyértelműen a gyermek évszázadának tekinthető, ekkor jelenik meg a reformpedagógia: a gyerekeket egyéniségként tisztelik, önálló gondolkozásra hajlamos és alkotómunkára képes lénynek tartják. A gyerek lélektani kutatások tárgyává válik. ${ }^{10}$ Az 1940-es évektől a gyerek szeretetre vágyó, törődést igénylő lény, és már nem csak tankönyvek szólnak róluk, hanem megjelennek a rájuk vonatkozó jogszabályok is, melyek szabályozzák a gyerekek gazdasági szerepét, társadalomban elfoglalt helyét és tiltják a számukra káros áruk (alkohol, cigaretta) fogyasztását. ${ }^{11}$

\footnotetext{
5 PUKÁNSZKY, A gyermekkor története 86-112.

${ }^{6}$ PUKÁNSZKY, A gyermekkor története 113-140.

7 PUKÁNSZKY, „A nevelés lényege: nem nevelünk” https://epa.oszk.hu/00000/00035/00031/1999-10-kfPukanszky-Neveles.html.

${ }^{8}$ PUKÁNSZKY, A gyermekkor története 142-165.

${ }^{9}$ Lásd VARGA, A kisdednevelés címú folyóirat gyermekképe, avagy engedelmesség pedagógiai dilemmái.

10 A korszak gyermeklélektannal foglalkozó pszichológiai múvei többek között John Broadus Watson (1878-1958) tollából a „Behavior: An Introduction to Comparative Psychology” című mű (1914), Jean Piaget (1896-1980) „The Child's Conception of the World” (1928) címú írása, Harry Harlow (1905-1981) „The Nature of Love” (1958), valamint John Bowlby (1907-1990) „Attachment. Attachment and Loss” (1969) című műve.

${ }^{11}$ PUKÁNSZKY, A gyermekkor története 169-190.
} 


\section{Nemzetközi egyezmények a gyermekjogokról}

A gyermekek egészen az 1900-as évekig nem voltak megkülönböztetett helyzetben a felnôttekhez képest, hosszú időn keresztül természetesnek tekintették, hogy a gyermekek kicsi felnőttek és legfeljebb arra a rövid időre szorulnak különleges bánásmódra, ameddig nem képesek magukról gondoskodni. ${ }^{12}$ Mai szemmel nézve felfoghatatlannak túnik, hogy a 19. században egy 6-7 éves gyermekrôl már azt gondolták, hogy nem szorul a szülei segítségére. Ha összevetjük ezt a 21. század, harmincas életéveikben is „Mama Hotelban” lakó fiataljaival, akkor szembetűnő, hogy az utóbbi évszázadban nagyot fordult a világ. Nem hiába mondta Ellen Key 1902-ben megjelent könyvében, hogy a 20. század a gyermekek évszázada lesz. ${ }^{13}$

A változások valóban a 20. század elején kezdődtek, ekkor már javában zajlottak a gazdasági és társadalmi fordulatok, melyek hatásásra a családszerkezetek is átalakultak, a nagycsaládok helyét a legtöbb helyen kezdték átvenni a nukleáris családok. Az egészségügyi szolgáltatások minőségének javulása miatt csökkent a gyermekhalandóság, illetve a mezőgazdasági termelés átalakulása, valamint a társadalombiztosítás és a nyugdíj bevezetése miatt már kevesebb gyermekre volt szüksége egy családnak a túléléshez, így minden családban egyre kevesebb gyermek született. A kevesebb gyermeket egyre jobban megbecsülték, ennek hatására a gyermekek speciális szükségleteire is egyre jobban odafigyeltek, észrevették, hogy a gyermekek nem kicsi felnőttek, hanem gondoskodásra, szeretetre vágyó teremtmények. A változások országonként és társadalmi rétegenként is eltérő ütemben zajlottak. ${ }^{14}$

A 20. század második felében a gyermekkorról és a gyermekek szükségleteinek felismeréséről, majd biztosításáról lassan áthelyeződött a hangsúly a gyermek jogainak feltérképezésére és összegyújtésére, ekkor születtek az első deklarációk. A következőkben igyekszem számba venni őket, hiszen nagy részük jelenleg is hatályos. Az egyes nemzetközi dokumentumok elfogadásában az Európa Tanács jár az élen, de fontos szerepe van az Európai Uniónak és az ENSZ-nek is.

Az első nem kötelező érvényű deklaráció már viszonylag korán, 1924-ben megszületett. $\mathrm{Az}$ ún. genfi nyilatkozat elôször fogalmazta meg a gyermekek védelmének általános igényét. Kimondta, hogy az éhező gyermeket táplálni kell, a beteget gyógyítani, a szellemi fejlődésben elmaradottat támogatni, a züllés útjára lépőt jó útra téríteni, az árva és elhagyott gyermekeket összegyújteni és támogatni. ${ }^{15}$

Ezt követte az 1948 decemberében az ENSz közgyúlése által elfogadott határozat, az Emberi Jogok Egyetemes Nyilatkozata. A benne foglalt egyetemes jogok minden embert, így a gyermekeket is megilletik, de a 25. cikk kiemeli, hogy a gyermekkor különleges gondoskodásra, támogatásra jogosít, valamint megtiltja a törvényes és törvénytelen gyermekek közötti különbségtételt a szociális jogok biztosítása területén.

Az 1950-ben Rómában elfogadott Emberi Jogok Európai Egyezménye sem kimondottan a gyermekek jogainak védelméről szól, hanem az általában minden embert, így a gyermeket is megilletô jogok katalógusát tartalmazza, többek között az igazságszolgáltatáshoz és a tisztességes eljáráshoz való jogot, melybe beletartozik a tájékoztatáshoz, meghallgatáshoz, a törvényes

\footnotetext{
12 PUKÁNSZKY, A gyermekkor története 19.

${ }^{13}$ JAKOBI, A gyermek évszázada javított változatban 17.

14 PUKÁNSZKY, A gyermekkor története 141-150.

${ }^{15}$ REIDERNÉ BÁNKI, A gyermek érdeke a felbomló családban 49.
} 
védelemhez és a képviselethez való jog. Két cikke napjainkban is kiemelkedő jelentőséggel bír, a gyermeket is érintő, az Emberi Jogok Európai Bírósága elé kerülő ügyek többségében ezen jogok megsértésére hivatkoznak. Nevezetesen a 8. cikkre, mely a magán- és családi élet tiszteletben tartásához való jogot garantálja, illetve a 14. cikkre, mely a diszkrimináció tilalmáról szól. Ezen szabályokat az Emberi Jogok Európai Bírósága gyermekek esetében is alkalmazhatónak tartja. Elvileg gyermek is fordulhat hozzájuk jogainak megsértése esetén, hiszen az eljárás kezdeményezője esetében nem feltétel a cselekvőképesség megléte, ennek ellenére ez nem túl gyakran fordul elő, pedig a New Yorki Egyezmény 3. kiegészítő jegyzőkönyve is az önálló eljáráskezdeményezés irányába mutat. ${ }^{16}$

Az 1959. november 20. napján az ENSz közgyúlése által elfogadott a Gyermekek Jogairól szóló Nyilatkozat elismerte, hogy a gyermeknek - figyelemmel fizikai és szellemi érettségének hiányára - különös védelemre és gondozásra van szüksége, nevezetesen megfelelő jogi védelemre, születése előtt és születése után egyaránt. A nyilatkozat még nem tartalmazta a gyermekjogoknak olyan kimerítő felsorolását, mint a 30 évvel később megszületett egyezmény, de néhány fontos dologra már felhívta a figyelmet, például a diszkrimináció tilalmára, a gyermek érdekének elsődlegességére, a gyermekek védelmének és segélyezésének minden körülmények közötti elsőbbségére, a gyermek egészségének védelmére és az egészségre káros munkavégzés tilalmára. Fontos különbség azonban, hogy ekkor még a gyermek az egyes jogosultságok tárgyaként, nem alanyaként jelent meg. ${ }^{17}$

Az 1961-ben Torinóban elfogadott Európai Szociális Charta $^{18}$ sem kimondottan a gyermek jogainak védelme céljából született, azonban deklarálja, hogy a gyermekeknek különleges védelemre van szükségük meghatározott területeken, például a munkavégzés során.

Az ENSz közgyúlése által 1966-ban megalkotott Polgári és Politikai Jogok Nemzetközi Egyezségokmánya részletesen felsorolja a minden embert, így a gyermekeket is megilletô klasszikus emberi jogokat, melyek közül legfontosabbak az élethez és az emberi méltósághoz való jog. Az egyezmény tartalmaz néhány gyermekekre vonatkozó rendelkezést is, elsősorban a büntetőjog és a büntetés végrehajtása területén, de tartalmaz szabályokat a diszkrimináció tilalmára vonatkozóan, illetve rendelkezik a kötelező anyakönyvezésről, valamint a gyermek jogainak védelméről a szülők házasságának felbontása során. ${ }^{19}$ Ezen egyezményhez szorosan kapcsolódik a szintén ebben az évben elfogadott Gazdasági és Szociális Jogok Nemzetközi Egyezségokmánya, mely a gyermekek tekintetében további részletes szabályokat tartalmaz elsősorban az oktatás és az egészségügy területén, valamint hangsúlyozza, hogy védeni kell ooket a kizsákmányolással szemben.

1966 meglehetősen termékeny év volt az alapvető jogok kodifikációja területén. A Hágai Nemzetközi Magánjogi Konferencia által elfogadott Hágai Gyermekvédelmi Egyezmény kimondta a gyermek legfőbb érdekének elsődlegességét, valamint felhívta a figyelmet arra, hogy a gyermekeket megillető jogok biztosítása érdekében nemzetközi összefogásra és együttmûködésre van szükség.

\footnotetext{
16 A 3. kiegészítő jegyzőkönyvhöz Magyarország még nem csatlakozott.

${ }^{17}$ NYITRAY, A gyermekjogi egyezmény 3. cikk 1. bekezdésének értelmezési és alkalmazási nehézségei 200.

${ }^{18}$ Az Európai Szociális Chartát az 1999. évi C. törvény hirdette ki Magyarországon.

${ }^{19}$ REIDERNÉ BÁNKI, A gyermek érdeke a felbomló családban 52.
} 
Ezt követően az ENSZ közgyúlése 1974-ben nyilatkozatot fogadott el a gyermekek védelméről, rendkívüli állapot és fegyveres konfliktusok idején, valamint felhívta a figyelmet arra, hogy védeni kell őket az elnyomástól, a kegyetlen, embertelen bánásmód minden formájától.

Az 1979 decemberében született New Yorki egyezmény deklarálta, hogy a férfiakat és a nőket közös felelősség terheli gyermekeik felnevelésében és fejlődésük biztosításában, valamint megerősítette, hogy a gyermek érdeke minden esetben elsődleges fontosságú szempont.

Máig jelentős szerepe van az 1980-ban elfogadott, a gyermekek jogellenes külföldre vitelének polgári jogi vonatkozásairól szóló hágai egyezménynek, azon belül is különösen a 12. és 13. cikkeknek, melyek lehetőséget biztosítanak az eljáró hatóságoknak arra, hogy a gyermek visszavitelének elrendelését megtagadják abban az esetben, ha a gyermek a jogellenes elvitel helyén már beilleszkedett, illetve, ha a visszavitel ôt testi vagy lelki károsodásnak tenné ki.

Az 1985-ös pekingi szabályok, azaz az ENSZ fiatalkorúak igazságszolgáltatási rendszerére vonatkozó minimum szabályai is jelentős mérföldkőnek számítanak, hiszen először hangsúlyozzák, hogy nem csak az elkövetés súlyára és körülményeire kell tekintettel lenni, hanem az elkövető személyi körülményeire, szükségleteire is. Korábban nem fordítottak kellő figyelmet arra, hogy a gyermek akkor is gyermek, és ehhez igazodó elbánást érdemel, ha történetesen bűnelkövető is. Gyermek elkövetők esetén nem az a társadalom legfőbb érdeke, hogy az illető méltó büntetést kapjon, sokkal inkább az, hogy visszatereljük őt a helyes útra. Természetesen ez a gyermek érdeke is.

A legnagyobb hatásúnak tekinthető, 1989-ben elfogadott, a Gyermek Jogairól szóló Egyezmény ${ }^{20}$ komoly változásokat hozott minden területen. Ezen Egyezmény hatására az akkor hatályos Csjt. ${ }^{21}$ jelentős - elsősorban szemléletbeli - változtatáson ${ }^{22}$ esett át, 1995 óta a gyermek jogai és az ő mindenek felett álló érdeke elsődlegesek az ôt érintő bírósági eljárásban hazánkban is. Az Egyezmény jelentôségét mutatja az is, hogy rövid időn belül a világ minden országa ratifikálta, kivéve két országot, Szomáliát és az Amerikai Egyesült Államokat, akik azóta sem csatlakoztak az egyezményhez.

Az 1990-es havannai szabályok az ENSz szabadságuktól megfosztott fiatalkorúak védelmére vonatkozó szabályait tartalmazzák. Az ehhez szorosan kapcsolódó rijadi iránymutatások hangsúlyozzák, hogy a fiatalkorú megbélyegzését mindenképpen el kell kerülni, mert bűnözői karrierhez vezethet ${ }^{23}$, ezért kiemelkedő jelentőségû, hogy a fiatalkorú elkövetôket csak végső esetben szabad szabadságuktól megfosztani. Erre utalnak a tokiói szabályok is.

Az 1993-ban elfogadott, a gyermekeknek a nemzetközi örökbefogadások terén való védelméről és az ilyen ügyekben való együttmúködésről szóló hágai egyezmény egy speciális területen igyekszik a gyermek érdekeinek védelmét és jogainak biztosítását garantálni.

Az Európa Tanács 1996-ban elfogadott egyezménye a gyermek jogainak gyakorlásáról külön hangsúlyt helyezett a gyermeket az eljárás során megillető jogokra, úgy mint releváns tájékoztatáshoz való jog, lehetőség álláspontja kifejtésére és annak megismerésére, hogy az eljárás eredményeképpen milyen esetleges döntések születhetnek, az általa elmondottak milyen

\footnotetext{
20 1989. november 20-án New Yorkban elfogadott ENSZ egyezmény, Magyarországon kihirdette az 1991. évi LXIV. törvény.

21 1952. évi IV. törvény a házaságról, a családról és a gyámságról.

22 A házasságról, a családról és a gyámságról szóló 1952. évi IV. törvény módosításáról szóló 1995. évi XXXI. törvény.

${ }^{23}$ Lásd FAIX, A gyermeki jogok kialakulása a nemzetközi jogban és az igazságszolgáltatásra gyakorolt hatása.
} 
következményekkel járhatnak. Az egyezmény arra is felhívja a figyelmet, hogy a gyermeknek lehetőséget kell biztosítani arra, hogy ügyvéd segítségét kérje, illetve egy bizalmas személy segítségére legyen véleménye megfogalmazása során. ${ }^{24}$

1996. október 19-én fogadták el a Hágai Gyermekvédelmi Egyezményt ${ }^{25}$, mely szintén fontos mérföldkő volt a gyermek jogainak garantálása terén. A további jogfejlődésre leginkább az egyezmény 23. cikke volt hatással. Napjainkban egyre több olyan ügy kerül a hatóságok elé, amelyben külföldön hozott határozatot kellene elismerni vagy végrehajtani. A 23. cikk rendelkezései szerint az elismerés megtagadásnak oka lehet, ha az intézkedést - sürgős eset kivételével - bírósági vagy közigazgatási eljárás során anélkül hozták, hogy biztosították volna a gyermek meghallgatásának lehetőségét, megsértve a megkeresett állam alapvető eljárási elveit.

2003-ban született az Európa Tanács Egyezménye a gyermekekkel való kapcsolattartásról, mely az egyik legalapvetőbb joga minden gyermeknek, és mivel nem csak jogi, hanem lélektani jelentősége is van a különélő szülővel való rendszeres találkozásoknak, ezen jogok garantálása kiemelt jelentôséggel bír.

A 2003-ban elfogadott nemzetközi elemet tartalmazó, szülői felelősséggel kapcsolatos ügyekben a joghatóságot, a határozatok elismerését és végrehajtását szabályozó Brüsszel II.a rendelet $^{26}$ számos rendelkezése szolgálja a gyerek jogainak garantálását. Például a 11. cikk értelmében biztosítani kell, hogy a gyermek lehetőséget kapjon az eljárások során történő meghallgatására, kivéve, ha ez a gyermek életkora vagy érettségi szintje miatt nem tûnik célszerűnek.

2005-ben Varsóban az Európa Tanács állam- és kormányfőinek 3. csúcstalálkozóján elfogadtak egy cselekvési tervet, majd 2007-ben Lanzaroteban az európai igazságügyminiszterek 28. konferenciáján öntötték végleges formába a gyermekbarát igazságszolgáltatásról szóló 2. sz. határozatot. 2008-ban négy jeles szakértő részletes jelentést készített az akkoriban fennálló akadályokról, kihívásokról. A jelentés eredményeinek értékelését követően 2008 szeptemberében a stockholmi konferencián valósult meg a nagy jelentőségú „építsük Európát a gyermekekért a gyermekekkel” elnevezésű, 2009-2011-ig szóló stratégia kialakítása. Ezt követte 2009 márciusában a toledói konferencia, mely „A gyermek védelme az európai igazságszolgáltatási rendszerekben” címet viselte. Az öt évig tartó előkészületeket követően, az iránymutatást 2010-ben végül egy a gyermekbarát igazságszolgáltatás szakértőiből álló csoport készítette el (CJ-S-CH csoport). ${ }^{27}$

2007-ben jött létre az Európa Tanács egyezménye a gyermekek szexuális kizsákmányolás és szexuális zaklatás elleni védelméről, mellyel korábban a New Yorki Egyezményhez füzött 2. kiegészítő jegyzőkönyv is részletesen foglalkozott.

Az 1989-es New Yorki Egyezmény könnyebb értelmezése és hatékonyabb alkalmazása érdekében alkották meg 2008-ban az egyezmény legújabb kommentárját, mely további szintlépést eredményezett a gyermeki jogok garantálása területén. ${ }^{28}$

\footnotetext{
${ }^{24}$ SZEIBERT, A családjogi harmonizáció kérdései és lehetőségei Európában 177.

25 2005. évi CXL. törvény a szülői felelősséggel és a gyermekek védelmét szolgáló intézkedésekkel kapcsolatos együttmúködésről, valamint az ilyen ügyekre irányadó joghatóságról, alkalmazandó jogról, elismerésről és végrehajtásról szóló, Hágában, 1996. október 19-én kelt Egyezmény kihirdetéséről.

${ }^{26}$ Európai Unió Tanácsa által hozott a házassági ügyekben és a szülői felügyeletre vonatkozó eljárásokban a joghatóságról, valamint a határozatok elismerésérôl és végrehajtásáról szóló 2201/2003 EK rendelet.

${ }^{27}$ GYURKÓ, Gyermekbarát igazságszolgáltatás 110-111.

28 Guidance Note of the Secretary-General - UN Approach to Justice for Children https://www.un.org/ruleoflaw/files/RoL_Guidance_Note_UN_Approach_Justice_for_Children_FINAL.pdf
} 
A 2009-es Európa Tanács Miniszteri Bizottságának ajánlása lényeges részletszabályokat tartalmaz a bentlakásos intézményben élő gyermekek jogairól. ${ }^{29}$

Az Európai Unió Alapjogi Chartája - mely az Európai Unió múködésérôl szóló szerződés részét képezi - deklarálja azokat a jogokat, melyek különösen fontosak a bírósági eljárásban részt vevő gyermekek jogainak biztosítása szempontjából. Ide sorolhatók a következő cikkek: az emberi méltóság (1. cikk), a kínzás vagy embertelen, megalázó bánásmód tilalma (4. cikk), a szabadsághoz és biztonsághoz való jog (6. cikk), a magán-és családi élet tiszteletben tartása (7. cikk.), a személyes adatok védelme (8. cikk.), a megkülönböztetés tilalma (21. cikk), a hatékony jogorvoslathoz való jog (47. cikk). A Charta egyik - gyermekjogok szempontjából legfontosabb cikke (24. cikk) alapelvként deklarálja a gyermekek vélemény kifejezéséhez való jogát, valamint megismétli, hogy véleményüket életkoruknak és érettségüknek megfelelően kell figyelembe venni. $^{30} 2010$ októberében az Európai Bizottság a Charta rendelkezéseinek hatékony érvényesítésére vonatkozó stratégiát (IP/10/1348), majd 2011 februárjában uniós ütemtervet fogalmazott meg. Az ütemterv célja, hogy az Alapjogi Chartában foglalt elvek gyakorlati megvalósulása valóban a gyermek jogainak érvényesülését szolgálja. Az ütemterv tizenegy egyértelmű intézkedést fogalmaz meg, többek között: a gyermekbarát igazságszolgáltatás elősegítése, a gyermek hatékonyabb tájékoztatása a jogaikról, a gyermek meghallgatásának körülményei, jogi képviselet biztosítása, az igazságszoltáltatás területén gyermekekkel dolgozó személyek interdiszciplináris képzése. ${ }^{31}$

Napjainkban az Európa Tanács által elfogadott szófiai gyermekjogi stratégia megvalósítása van napirenden, mely 2016-ban kezdődött és 2021-ig igyekszik a következő területeken meghatározott célkitűzéseket megvalósítani: egyenlő esélyek biztosítása, a gyermek részvétele az eljárásban, erőszakmentes élet biztosítása, a digitális környezetben biztosított jogok garantálása, valamint a gyermekbarát igazságszolgáltatás. Továbbá az Európa 2020 stratégia (IP10/225) és a stockholmi program végrehajtására vonatkozó bizottsági cselekvési terv (IP/10/447) legfontosabb célkitúzése, hogy a gyermekek a lehető legjobb minőségű oktatásban és nevelésben részesülhessenek, és jogaik is maradéktalanul érvényesülhessenek. Ezen programok arról árulkodnak, hogy hiába telt el közel száz év az első gyermekjogokkal foglalkozó deklaráció megszületése óta, még mindig vannak - elsősorban a gyakorlati megvalósítás terén jelentkező hiányosságok.

\section{A gyermekjogok hazai szabályozásának lépcsői}

Első nagyobb jelentőségű családjogi szabályozási körre kiterjedő jogszabályunk, a házassági jogról szóló 1894. évi XXXI. törvény még nem rendelkezett kimondottan a gyermek jogairól, a bontó okok körében azonban találhatunk olyanokat, amelyek a gyermek jóllétének biztosításával összefüggésben születtek, azaz a bíróság a felek házasságát felbontotta, ha valamelyik fél a házastársak családjához tartozó gyermeket bűncselekmény elkövetésére vagy erkölcstelen életre bírta rá, vagy arra törekedett. Itt az elsődleges cél még nem a gyermek jogainak védelme volt, de

${ }^{29} \mathrm{CM} / \operatorname{Rec} 2009$ 10.sz Recommendation CM/Rec (2009)10 of the Committee of Ministers to Member States on Integrated National Strategies for the Protection of Children from Violence https://rm.coe.int/168046d3a0

30 Gyermekbarát igazságszolgáltatás - a gyermekek és a szakemberek álláspontja és tapasztalatai. Összefoglaló. https://fra.europa.eu/sites/default/files/fra_uploads/fra-2017-child-friendly_justice-summary_hu.pdf.

${ }^{31}$ NAGY, A gyermek jogainak érvényesülése az igazságszolgáltatásban 52. 
már egyértelműen közvetít egy felfogást, mely szerint a gyermek ilyen módon történő „bántalmazása” olyan súlyos vétek, amely a házasság felbontásához is kellő okot adhat.

A második világháborút követően meglehetôsen sok rendezetlen családi jogállású gyermek született, mely állapotnak komoly következményei voltak a gyermek egész életére nézve. Ezen negatív megítélés elkerülése érdekében született meg - Európában is úttörő módon - az 1946. évi XXIX. törvény a törvényes és törvénytelen gyermek közötti megkülönböztetés eltörlése érdekében, mely kimondta, hogy azonos jogok illetik a gyermekeket függetlenül attól, hogy házasságban, vagy házasságon kívül születtek.

Az 1949. évi XX. törvény, azaz a 2011. december 31. napjáig hatályban volt Alkotmányunk külön kiemelte, hogy „a Magyar Népköztársaság kïlönös gondot fordít az ifjúság létbiztonságára, oktatására és nevelésére, valamint védelmezi az, ifjúság érdekeit.” A törvény a gyermek helyett az ifjúság kifejezést használja és elsősorban a szocialista állam feladatává teszi a fiatalok legfontosabb jogainak biztosítását. Az Alkotmány 1989-es módosítását követően így fogalmazott: a Magyar Köztársaságban minden gyermeknek joga van a családja, az állam és a társadalom részéről arra a védelemre és gondoskodásra, mely a megfelelő testi, szellemi és erkölcsi fejlődéséhez szükséges, tehát a gyermekek jóllétének biztosítása már nem csak az állam feladata.

A 2011-ben elfogadott Alaptörvény több cikke is utal a gyermeki jogok biztosításának elsődlegességére, szavatolja például, hogy „Magyarorsqág külön intézkedésekkel védi a családokat, a gyermekeket, a nöket, az. idöseket és a fogyatékekal élóket”. ${ }^{2}$ Kifejezi továbbá, hogy „minden gyermeknek.

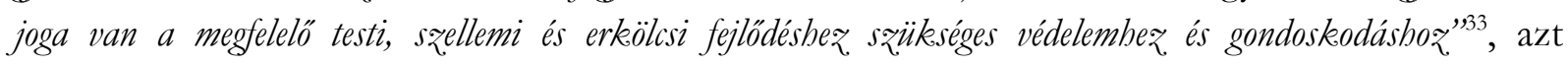
azonban nem részletezi, hogy mindezt kinek kell biztosítani számukra. Egyedül a nevelés és taníttatás területén ad iránymutatást, mikor kimondja, hogy „a szülök kötelesek kiskorú gyermekü̈kröl gondoskodni. E kötelezettség magában foglalja gyermekïk tanittatását." Cserébe azonban tisztázza a gyermekeket terhelő kötelességet is, miszerint „a nagy/korú gyermekek kötelesek rászoruló szüleikröl gondoskodni. ${ }^{\not 34} \mathrm{Az}$ Alaptörvény XVIII. cikke is utal a gyermekeket megilletô jogokra: ,a gyermekek foglalkoztatása - testi, szellemi és erkeölcsi fejlödésüket nem veszélyeztetö, törvényben meghatározott esetek. kivételével - tilos. Magyarország külön intézkedésekelel biztositja a fiatalok és a szülók munkahelyi védelmét." Azzal, hogy nem sorolja fel a gyermeket megillető összes jogot az Alaptörvény, valójában nem követ el mulasztást, hiszen a New Yorki Egyezmény jogrendszerünk immanens része, alkalmazása mind a szülők, mind az állam nevében eljáró hatóságok, mind a gyermekkel kapcsolatba kerülő egyéb személyek számára kötelező, valamint alapelvei már korábban beépültek a gyermeket is érintő jogszabályokba.

Szintén 2011-ben született a családok védelméről szóló törvény ${ }^{35}$, amely a kiskorú gyermeket nevelő szülők kötelességeit is felsorolja: a gyermek emberi méltóságának tiszteletben tartása, a gyermekkel való együttmúködés, a gyermek tájékoztatása az őt érintő ügyekben.

A házasságról, a családról és a gyámságról szóló 1952. évi IV. törvény - mely hosszú időn keresztül szabályozta a családjogi viszonyokat - eredeti célkitűzései között is szerepelt a gyermekek érdekeinek védelme, az ifjúság fejlődésének és nevelésének előmozdítása az Alkotmánnyal összhangban, ám ennél konkrétabb szabályokat nem tartalmazott a gyermek jogainak biztosításával kapcsolatban. Ebben jelentős változást hozott az 1991. évi LXIV.

\footnotetext{
32 Magyarország Alaptörvénye XV. cikk (5) bekezdés.

${ }^{33}$ Magyarország Alaptörvénye XVI. cikk.

${ }^{34}$ Magyarország Alaptörvénye XVI. cikk.

35 2011. évi CCXI. törvény a családok védelméről.
} 
törvénnyel ratifikált New Yorki Egyezmény, melynek hatására 1995-ben jelentős átalakításon esett át a Csjt. Alapelvi szinten rendelte el, hogy „a törvény alkalmazása során mindenkor a kiskorú gyermek érdekére figyelemmel, jogait biətositva kell eljárni".

Az 1997-ben megalkotott 1997. évi XXXI. törvény a gyermek védelméről és a gyámügyi igazgatásról, valamint a hozzá kapcsolódó 149/1997 (IX.10) kormányrendelet is alapelvei között biztosítja, hogy alkalmazása során tekintettel kell lenni a gyermek alapvető érdekeire, mindenkor ezen érdekek biztosítására kell törekedni.

A 2014-ben hatályba lépett 2013. évi V. törvény Családjogi Könyvének kodifikációjára már erős hatást gyakoroltak az ENSZ, az Európai Unió, a Hágai Nemzetközi Magánjogi Konferencia és az Európa Tanács által elfogadott deklarációk, egyezmények és iránymutatások, így a jogszabály megalkotása során már nem is volt kérdés, hogy a gyermek legfőbb érdekének elsődlegessége alapelvként kerül meghatározásra, azaz az egész jogszabály értelmezését áthatja, azt alapvetően határozza meg.

A Ptk. 4:2 \-a rögzíti, hogy „a családi jogviszonyokban a gyermek érdeke és jogai fokozott védelemben részesülnek”. Ezen deklaráció szoros összefüggésben van a családi jog általános alapelveivel, hiszen a gyermek, aki korából és élethelyzetéből adódóan a családi kapcsolataiban eleve a gyengébb fél helyzetében van, különleges védelemre és támogatásra szorul. Egyértelmú a jogalkotó szándéka, miszerint a gyermek ne a tárgya legyen a hatósági eljárásoknak, ne csak passzív elszenvedője legyen szülei döntésének, hanem legyen ő az eljárás legfőbb érdekeltje, akit minden fontos dologról tájékoztatni kell, azokkal kapcsolatban joga van véleményét kinyilvánítani és ahhoz is joga van, hogy nyilatkozatát - korának és érettségének megfelelően - kellő súllyal figyelembe is vegyék. ${ }^{36}$

Magyarország kormánya 2012-ben meghirdette a gyermekközpontú igazságszolgáltatás évét, melynek egyik legfontosabb célja volt azon körülmények és eljárási szabályok megalkotása, melyek garantálni képesek, hogy a bírósági meghallgatás a gyermekek számára ne egy életre szóló negatív élmény legyen. Eredményeképpen született meg a 2012. évi LXII. törvény, mely számos törvényt módosított, többek között a Btk.-t, a Be-t, a Bvtvr.-t, és a Pp.-t. Azóta ezeket a jogszabályokat hatályon kívül helyezték, hiszen új törvény készült helyettük, de az alapvetô elvek megmaradtak, beépültek az új szabályok közé. További eredménye volt a 2012-ben indult kezdeményezésnek, hogy 2013-ban az Országos Bírósági Hivatalon belül a gyermekközpontú igazságszolgáltatás bírósági koncepciójának kialakítására munkacsoportot állítottak fel. Tevékenységük nyomán több tájékoztató született az eljárásban bármilyen minőségben részt vevő gyermekek számára.

\section{A gyermek jogai a szülők „válása” esetén}

A 21. századra egyértelmúen eljutottunk oda, hogy ma már nem vitás, a gyermek életkorából adódó védtelensége miatt az alapvető emberi jogokon túl is speciális védelemre szorul, különleges bánásmódot érdemel. Az imént felsorolt és röviden bemutatott dokumentumok jól illusztrálják ezt a fejlődési folyamatot. 2020-ban a gyermekjogok több szinten biztosított, minden élethelyzetre kiterjedő katalógusával találkozhatunk, a szabályozás tehát megfelel az elvárásoknak,

\footnotetext{
${ }^{36}$ Boros - KATONÁNÉ PEHR - KŐRÖS - MAKAI - SZEIBERT, Az új Ptk. magyarázata 28.
} 
most már csak annyi dolgunk van, hogy elérjük, ezen jogok érvényre juttatása minden felnőtt és gyermek számára magától értetődő legyen. Ezen a területen még van hova fejlődni.

Közhelynek számít a kijelentés, miszerint a szülők válása életre szóló sebet ejt a gyermek lelkén, melynek valóságtartalmát egyetlen pszichológus sem kérdőjelezi meg, miközben hangsúlyozzák: nem a szülők kapcsolatának felbomlása káros a gyermek számára, hanem a folyamat és annak minősége. Fontos tehát, hogy a szülők tiszteletben tartsák gyermekük jogait, tekintettel legyenek a legfőbb érdekére és megóvják a lelki sebektől is.

A gyermek jogainak biztosítása a szülők és az eljárásban részt vevő egyéb szereplők: bíróság, gyámhatóság, szakértők közös feladata. A következőkben a gyermek legfontosabb jogait emelem ki, melyeket az eljárás során garantálni kell számára.

A gyermeknek joga van ahhoz, hogy tájékoztassák. Ezen kötelesség először a szülők oldalán jelentkezik, hiszen az egész folyamat azzal kezdődik, hogy hoznak egy döntést, miszerint a továbbiakban külön utakon folytatják az életüket. Ezt a döntést a gyermekkel is közölni kell, nem szabad abból kiindulni, hogy úgysem érti mi zajlik körülötte. Életkorának és érettségének megfelelően el kell neki magyarázni, hogy miként fog megváltozni az élete. Ezt követően jellemzően elindul egy jogi folyamat is: a házasság felbontása, a szülói felügyelet és az ehhez kapcsolódó kérdések - kapcsolattartás, gyermektartás - rendezése. Az eljárás során az igazságszolgáltatás és a közigazgatás szerveinek is kötelessége a gyermeket folyamatosan tájékoztatni, illetve a végső döntés megismerésére is jogosult, olyan formában, amely számára is érthető.

A gyermeknek azonban nem csak ahhoz van joga, hogy megkapja a szükséges felvilágosítást, hanem lehetőséget kell biztosítani számára, hogy a folyamatban aktívan részt vehessen, sorsának alakításába beleszólást kaphasson. Joga van ahhoz, hogy véleményét szabadon kifejezze, azt meghallgassák és a döntéshozatal során figyelembe is vegyék. Mindezt természetesen életkorának és érettségének megfelelő mértékben. A polgári peres, illetve a gyámhatóság előttt folyó eljárások sokszor a felnőttek számára is nehézséget jelentenek, laikusként nem könnyű eligazodni a jogszabályok útvesztójében, egy gyermek számára pedig egyenesen értelmezhetetlen lehet minden, ami körülötte történik. Joga van tehát ahhoz, hogy segítséget kapjon, egy a szüleitől független személy formájában. Ez hazánkban még meglehetôsen gyermekcipőben jár, főleg azért, mert a segítő nem automatikusan jelenik meg a gyermek oldalán. Sok szülő és gyermek nem is tudja, hogy kitől kérhet segítséget.

Alapvető, hogy az eljárás során a gyermek emberi méltóságát tiszteletben kell tartani, mind az eljárásban részt vevő személyeknek, mind a szülőknek, de a sajtónak is, akik gyakran nincsenek erre tekintettel. A gyermeket védeni kell a diszkrimináció minden formájával szemben, hiszen minden gyermek egyenlő és ugyanolyan védelmet érdemel. Ugyanez igaz a tisztességes eljáráshoz való jogra is.

Az ENSZ Gyermekjogi Bizottsága, amely a Gyermek jogairól szóló Egyezményben foglalt követelmények betartása felett őrködik, 2020-ban készítette el záró észrevételeit ${ }^{37}$, melyben kiemelte, van még hova fejlődni a magyar szülőknek és hatóságoknak, mert még mindig nem fordítunk kell figyelmet arra, hogy a gyermeket valóban meghallgassuk és véleményét figyelembe

\footnotetext{
37 A bizottság 83. ülésén (2020. január 20. - február 7.) fogadta el a dokumentumot. Nem hivatalos fordításban elérhető: http://www.csagyi.hu/images/stories/kutatas/enszjelentesek/crc-c-hun-co-6-zaro-eszrevetelek-hunwm_1.pdf.
} 
vegyük. Úgy tűnik a szülők még mindig úgy gondolják, hogy a gyermeket nem kell a felnőttek dolgába bevonni és teljesen rendben van az, hogy az ő sorsát is érintő döntéseket a megkérdezése nélkül, a „feje felett” hozzák meg.

\section{A gyermek mindenek felett álló érdekének szem előtt tartása a „válás” során}

A New York-i egyezmény alaptétele, mely elfogadása óta minden, a gyermek jogairól szóló jogszabály kiindulópontja, az eredeti angol nyelvü szövegben ,the best interest of the child" szóhasználattal jelent meg. Az első magyar változatban kissé helytelenül a gyermek mindenek felett álló érdekének lett fordítva. Először Herczog Mária vetette fel, hogy általánosságban nem beszélhetünk a gyermek mindenek felett álló érdekéről, hiszen sok esetben egyéb más szempontok vagy adott esetben más gyermekek érdekei is ütközhetnek, így napjainkban a sokkal inkább helyénvaló és az eredeti szándékot is jobban tükröző megfogalmazást használjuk: a gyermek legfőbb érdeke vagy a gyermek legjobb érdeke. ${ }^{38}$

A szóhasználat eltéréséből adódó félreértéseken túl is nehézséget okoz, hogy valójában sehol nincs meghatározva, hogy pontosan mit is jelent a gyermek legfőbb érdeke, pedig világos jogi kritériumrendszer kidolgozásával sokat segíthetnénk a jogok biztosításában. De biztos, hogy azzal garantáljuk a gyermek érdekének érvényesülését, ha rugalmatlan, merev szabályok közé szorítjuk?

Az ENSZ Gyermekjogi Bizottsága által 2013-ban elfogadott 14. számú átfogó kommentár szerint a gyermek legfóbb érdeke három részből áll. Jelent egyrészt egy alanyi jogot arra, hogy konkrét ügyben, több egymással ütköző érdek esetén a gyermek érdeke legyen az elsődleges. Továbbá alapvetô értelmezési alapelvként is szolgál, azaz, ha egy rendelkezésnek többféle értelmezése is lehetséges, akkor azt az értelmezést kell figyelembe venni, amelyik a legjobban szolgálja a gyermek érdekét. Végül eljárási szabályként is értelmezhető, hiszen az egész eljárást úgy kell lefolytatni, hogy annak folyamata során és a végeredmény tekintetében is a gyermek álljon a középpontban. ${ }^{39}$

Tovább nehezíti a gyermek legfőbb érdekének meghatározását, hogy az eljárás során a gyermek összes, a New Yorki Egyezmény szerint biztosított jogát tiszteletben kell tartani, hiszen ezen garantált jogok között nem állíthatunk fel fontossági sorrendet, azok elvileg mind a gyermek legjobb érdekét szolgálják. ${ }^{40}$

Ahhoz tehát, hogy megtalálhassuk azt a megoldást, amely a gyermek legfóbb érdekét biztosítja, az eset összes körülményét, az ügy egyéb érdekeltjeinek érdekeit (szülők, más gyermekek) valamint a gyermeket megillető minden egyéb jogot együttesen, gondos mérlegelés alá kell vonni és figyelembe kell venni a rövid és hosszútávú következményeket is. Ezért nagyon fontos, hogy a szülők a kezdetektől bevonják a gyermeket a folyamatba, ügyelve arra, hogy az ezzel járó terhektől közben megkíméljék, azaz nem a konfliktusba, hanem a döntéshozatalba kell ôt bevonni. A kezdetek alatt pedig azt értem, hogy a gyermeket egész kicsi korától kezdve úgy kell nevelni, hogy érezze, ő is fontos része a családnak, az ő véleménye is számít és bízhat abban, hogy a szülei a családot érintő döntések meghozatalába őt is bevonják. Ilyen körülmények között

\footnotetext{
${ }^{38}$ NYITRAY, A gyermekjogi egyezmény 3. cikk 1. bekezdésének értelmezési és alkalmazási nehézségei 197.

${ }^{39}$ BARZÓ, A gyermek érdekének védelmét erôsítő családjogi alapelv 41-42.

${ }^{40}$ FAZEKAS, A gyermeki jogok érvényesülése az új Polgári Törvénykönyv Családjogi Könyvében 40.
} 
felnőve természetes lesz számára, hogy a válással kapcsolatban is kikérik a véleményét, sôt ezt a hozzáállást viszi majd magával a felnőtt életébe, a saját szülőségébe.

Figyelemmel kell lenni arra is, hogy a gyermek érdeke sok esetben ellentétes a szülők érdekével, erre azonban nem biztos, hogy időben fény derül, hacsak nem vagyunk kellóképpen körültekintőek. Amennyiben érdekellentét áll fenn, arra kell törekedni, hogy megtaláljuk az egyensúlyt a gyermek érdeke és a szülők érdeke között, hiszen a gyermek érdeke nem mindenek felett áll, csak a legfőbb szempontként érvényesül. Ezért is fontos a megfelelő szóhasználat.

Fontos lenne - többek között a jogalkotói szándék maradéktalan érvényre jutása érdekében -, hogy az eljárást lezáró határozatból kitűnjön, mit tekintett az eljáró hatóság a gyermek legfőbb érdekének. Annak ellenére a legtöbbször hiányzik ennek kimondása, hogy a határozatot elvileg ennek alapján hozták meg. Magyarországon a bíró (remélhetôleg) az ügy összes körülményének mérlegelésével hozza meg ítéletét, azaz maga dönt arról is, hogy mi a gyermek legfőbb érdeke. A másik lehetőség, hogy a szülők egybehangzó nyilatkozatára hagyatkozik, de más bizonyítási eszközt ritkán vesz igénybe.

A gyermek legfőbb érdekének meghatározása elvileg minden eljárás alapjául kellene, hogy szolgáljon. Minden házasság felbontására vagy szülői felügyelet rendezésére irányuló pernek vagy gyámhatósági eljárásnak innen kellene indulni. Amennyiben a szülők egy kész vagy félkész megállapodással érkeznek a bíróságra, amelyben már előre rendelkeztek a szülői felügyelet gyakorlásáról - általában erről tudnak a legkönnyebben egyezségre jutni - a bíróság nem vizsgálja, hogy a szülei által hozott döntés a gyermek érdekét szolgálja-e. A Ptk. szerint a szülőknek olyan megoldást kell választaniuk, amely a gyermek testi, értelmi és erkölcsi fejlődését legjobban biztosítja. ${ }^{41}$ A bíróságnak vizsgálnia kellene tehát - az új polgári perrendtartás vonatkozó rendelkezéseinek megfelelően - az egyezséggel kapcsolatban a befolyástól mentességet, mindkét féllel szembeni méltányosságot és azt, hogy az a gyermek érdekének megfelelő-e. ${ }^{42}$ Amennyiben a feltételek nem állnak fent az egyezség nem hagyható jóvá. Az egyezség jóváhagyása során a gyermek érdekének meghatározása és figyelembevétele legtöbbször kimerül abban, hogy a bíró megkérdezi a szülőket, hogy a döntés meghozatala előtt kikérték-e a gyermek véleményét.

Amennyiben a szülők nem tudnak egymással megállapodni és a bíróságnak kell a szülői felügyeletről szóló döntést meghozni, valamivel több esély van a gyermek érdekének figyelembevételére. A bizonyítási eljárás nagyobb mozgásteret biztosít a bírónak, melyben elsősorban a pszichológus szakértői vélemény és a gyermek meghallgatása szolgálhat bizonyítékkal a gyermek érdekének meghatározása során. Ebben az esetben tehát a bíró - a pszichológus és a gyermek segítségével - határozza meg a gyermek számára legjobb megoldást, azonban, mivel az itélet meghozatala után nincs lehetőség a család életének utánkövetésére, soha nem lehet biztos abban, hogy valóban az volt a gyermek érdeke, amit ő annak látott.

Nem könnyű tehát meghatározni, hogy mi a gyermek érdeke, hiszen ez számtalan tényező és körülmény függvénye, sôt az idő múlásával akár változhat is, mégis van néhány fontos szempont, melynek szem előtt tartása segítségünkre lehet. Amit soha nem felejthetünk el: a gyermek nem az eljárás tárgya, nem lehet passzív elszenvedője szülei döntésének, hiszen ő az eljárás legfőbb érdekeltje, a döntéshozatalba őt mindenképpen be kell vonni. Ami minden körülmények között igaz: a gyermek legfőbb érdeke egy békés, konfliktusoktól mentes válás,

\footnotetext{
${ }^{41}$ A Ptk. 4:147. \(1) bekezdés alapján.

${ }^{42}$ Hegedüs, Polgári jog - családjog 80.
} 
amelyben neki nem a villámhárító, a közvetítő vagy a fegyver szerepét szánják. Ez azért is fontos, mert csak így garantálhatjuk, hogy szoros és kielégítő kapcsolata maradjon fenn mindkét szülővel. A gyermeknek rövid- és hosszútávon is alapvető érdeke a stabilitás, a biztonság, a kiszámíthatóság, ezt senki sem veheti el tőle, hiszen Gyurkó Szilvia szavaival egyetértve: a gyermekkor egyszeri és megismételhetetlen.

\section{Miként rombolhatjuk a gyermek jogait és legfőbb érdekét?}

Az eddig ismertetettek alapján olyan egyszerűnek túnik minden. A szülők kapcsolatának felbomlása során csak arra kell ügyelni, hogy a gyermek jogait tiszteletben tartsák és a döntések meghozatala során az ő legfőbb érdekét tartsák szem előtt. Jogait már ismerjük, érdeke meghatározásának szempontjai világosak. Miért nem múködik akkor? Milyen hibákat követhet el a bíróság, illetve a szülők?

A gyermek jogainak és legfőbb érdekének elsődlegessége az 1991. évi LXIV. törvény óta megkérdőjelezhetetlen, de ennek köztudatban való elterjedése és a bírósági eljárásokban való valódi megjelenése inkább a 2010-es évek óta jellemző, tehát nem mondhatjuk, hogy a gyermekjogi világnézetnek évtizedes hagyományai lennének, így nem meglepő, hogy még nagyon sokat kell tanulnunk.

A bíróság által elkövetett hibák jellemzően a végletekben jelentkeznek, azaz az elhúzódó vagy a nagyon gyors döntéshozatalban. A gyermek szempontjából mindkettő káros lehet, de ilyen esetekben eleve két gyermeki érdek ütközik egymással. Egyrészt fontos, hogy az eljárás a lehető legrövidebb ideig tartson, hogy minél hamarabb véget érjen a bizonytalanság a gyermek jövőjét illetően, ugyanakkor az sem elhanyagolható szempont, hogy a bíróságnak széleskörü bizonyítási eljárást kell lefolytatnia ahhoz, hogy biztos lehessen a gyermek legfőbb érdekét illetően. Az arany középút megtalálást segíthetnék speciális - családjogi perekben alkalmazható - határidők, esetleg egy külön családjogi bíróság felállítása, ahol a bírák speciális szakértelemmel bírnak.

A másik hiba szintén a végletekben érhetô tetten: a gyermek csekély mértékű vagy túlzott bevonása az eljárásba. Az utóbbi években - a továbbképzéseknek köszönhetően - ezen a téren sokat fejlődtek a magyar bírák, de még mindig sok bizonytalanság tapasztalható. Személyes tapasztalatom szerint kicsi gyermekek esetében még mindig a szülők nyilatkozatára hagyatkoznak, nagyok esetében pedig sokszor túlzásokba esnek és akár több alkalommal is meghallgatják a gyermeket.

A szülők jellemzően azért veszik semmibe a gyermek jogait, vagy értelmezik félre a legfőbb érdekét, mert az eljárás során elsorban a saját, egymással szembeni indulataik foglalják le őket. Sokszor csak a másik fél legyőzésére törekszenek és egyáltalán nincsenek tekintettel a gyermekre, noha legtöbbször éppen őrá hivatkoznak. Tovább fokozza a nehézségeket, hogy nem ismerik fel a helyzet kialakulásában a saját felelősségüket és egy kívülállótól: a bíróságtól vagy az ügyvédektől várják a megoldást.

A szülők legtöbbször azt hiszik, egyedül ők tudják mi a gyermek érdeke, melynek során abból indulnak ki, hogy ami nekik jó, az a gyermeknek is az. Teszik mindezt úgy, hogy a gyermeket nem kérdezik meg, az eseményeket nem magyarázzák meg, a döntés következményeire a gyermeket nem készítik fel, sőt, ami a legrosszabb, a gyermeket a másik szülő ellen nevelik. 


\section{7. Összegzés}

Mint láthattuk nem elegendő a gyermek jogait katalogizálni, legfőbb érdekének biztosítását törvénybe foglalva alapelvként meghatározni, de érvényre juttatásukat is garantálni kell. Ez elsősorban a szülők és az eljáró hatóságok feladata, de a társadalom egészének is ki kell vennie belőle a részét. A gyermeknek vannak tehát jogai, de azok csak a felnőtteken keresztül érvényesülhetnek.

Az ember az idők kezdete óta családban él, a mai napig ez képezi minden társadalom legfontosabb alapegységét. A párkapcsolatra és a családi életre a családi szocializáció során készülünk fel és ma már azt is tudjuk, hogy a családi minták generációról generációra öröklődnek, nagyon nem mindegy tehát, hogy milyen példával szolgálunk gyermekeinknek. De nem csak az együttélésre és a gyermeknevelésre kell felkészülni, hanem a válásra is. A gyermek számára természetesen az a legjobb, ha egy boldog, szeretô és támogató családban nő fel, de ennek a családnak nem feltétlenül kell hagyományos értelemben vett családnak lenni, ahol a szülők egy háztartásban élnek. Sajnos a párkapcsolatok jelentôs része felbomlik, de ennek nem szabad egyúttal a család felbomlását is eredményezni, mert a gyermek érdekét az szolgálja, ha mindkét szülőjével megmarad a szoros kapcsolata, ehhez azonban az kell, hogy egymással együtt tudjanak múködni, aminek alapvető feltétele, hogy a válásuk konfliktusoktól mentes legyen. Sajnos a szülőknek jellemzően nagyon rossz mintáik vannak arra, hogy miként zajlik egy válás. Ezt látták a szüleiktől, barátaiktól, erről olvasnak az újságban és sokszor nem is tudják, hogy ezt másképpen is lehetne, talán eszükbe sem jut, hogy ezzel mennyit ártanak a gyermeknek. Ezért lenne fontos szerepe a mediáció minél szélesebb körben való megismertetésének, mert a közvetítés során nem csak egy mindenki számára elfogadható és kielégítő megállapodás elérése a cél, hanem a konfliktusok elsimítása, a kommunikáció helyreállítása. Ebben nagyon fontos szerepe van az ügyvédeknek és a bíróknak is, hogy megismertessék a szülőkkel ezt a lehetőséget. ${ }^{43}$

\section{Felhasznált irodalom és források}

1989. november 20-án New Yorkban elfogadott ENSZ egyezmény kihirdetéséről szóló 1991. évi LXIV. törvény.

A családok védelméről szóló 2011. évi CCXI. törvény

A házasságról, a családról és a gyámságról szóló 1952. évi IV. törvény

A házasságról, a családról és a gyámságról szóló 1952. évi IV. törvény módosításáról szóló 1995. évi XXXI. törvény

A Polgári Törvénykönyvről szóló 2013. évi V. törvény

Az ENSz Gyermekjogi Bizottsága 2020. évi jelentése

http://www.csagyi.hu/images/stories/kutatas/enszjelentesek/crc-c-hun-co-6-zaro-eszrevetelek-hunwm_1.pdf. (2021.01.31.)

Az Európai Unió Tanácsa által hozott a házassági ügyekben és a szülői felügyeletre vonatkozó eljárásokban a joghatóságról, valamint a határozatok elismeréséről és végrehajtásáról szóló 2201/2003 EK rendelet

BARZÓ Tímea: A gyermek érdekének védelmét erősítő családjogi alapelv érvényesülésében felmerülő ellentmondások. Opuscula Civilia 2017/2. sz.

Boros Zsuzsa - Katonáné PeHr Erika - Kőrös András - MAKAi Katalin - Szeibert Orsolya: Az új Ptk. magyarázata, Polgári Jog, Családjog. Budapest 2013

FAIX Nikoletta: A gyermeki jogok kialakulása a nemzetközi jogban és az igazságszolgáltatásra gyakorolt hatása.

43 Ebben segíthetnek az olyan válásközpontok, mint például a „Szépen válj el” válásközpont, lásd: https://szepenvaljel.hu/. 
Eljárásjogi Szemle, 2016/4. https://eljarasjog.hu/2016-evfolyam/a-gyermeki-jogok-kialakulasa-anemzetkozi-jogban-es-az-igazsagszolgaltatasra-gyakorolt-hatasuk/ (Letöltés: 2021. 05.10.)

FAZEKAS Ágota: A gyermeki jogok érvényesülése az új Polgári Törvénykönyv Családjogi Könyvében. Pro Futuro 2016/2. sz.

Guidance Note of the Secretary-General - UN Approach to Justice for Children.

https://www.un.org/ruleoflaw/files/RoL_Guidance_Note_UN_Approach_Justice_for_Children_FINAL. pdf (Letöltés: 2021. 07. 24.)

Gyermekbarát igazságszolgáltatás - a gyermekek és a szakemberek álláspontja és tapasztalatai. Összefoglaló. https:// fra.europa.eu/sites/default/files/fra_uploads/fra-2017-child-friendly_justice-summary_hu.pdf (Letöltés: 2019. 03. 23.)

GYURKÓ Szilvia: Gyermekbarát igazságszolgáltatás. In: VÓKÓ György (szerk.): Kriminológiai Tanulmányok 49. Budapest 2012, 110-111.

GYURKÓ Szilvia: Rám is gondoljatok - A gyermekközpontú válás lépései. Budapest 2015

HEGEDŰs Andrea: Polgári jog - családjog. Szeged 2017

HoLLÓsI Hajnalka: Gyermekkép, gyermekvilág, gyermekfelfogás változásai pedagógiai megközelítésben. Iskolakultúra, Online 2008/2. sz.

JAKOBI, Juliane: A gyermek évszázada javított változatban - az Ellen Key recepció újraértelmezése. Iskolakultúra 2005/9. sz.

NAGY Márta: A gyermek jogainak érvényesülése az igazságszolgáltatásban. Budapest 2018

NYITRAY Zsuzsanna: A gyermekjogi egyezmény 3. cikk 1. bekezdésének értelmezési és alkalmazási nehézségei. https://edit.elte.hu/xmlui/bitstream/handle/10831/35652/Jogi_tan_2012_2_Nyitray_Zsuzsanna_p_197210.pdf;jsessionid=E7B7E1F9A18169B6F465FD64E8696E44? sequence=1 (Letöltés: 2021. 01. 27.)

PUKÁNSZKY Béla: A gyermekkor története. Budapest 2001

PUKÁNSZKY Béla: „A nevelés lényege: nem nevelünk” Gondolatok Ellen Key könyvének olvasása közben. https://epa.oszk.hu/00000/00035/00031/1999-10-kf-Pukanszky-Neveles.html (Letöltés: 2021. 01. 21.)

REIDERNÉ BÁNKI Erika: A gyermek érdeke a felbomló családban. Győr 2014

SZEIBERT Orsolya: A családjogi harmonizáció kérdései és lehetőségei Európában. Budapest 2014

VARGA László: A kisdednevelés címú folyóirat gyermekképe, avagy engedelmesség pedagógiai dilemmái. Neveléstörténet 2006/1-2. sz. 